\title{
Creating a Book Club with a Critical Approach to Foster Literacy Practices
}

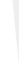

La creación de

clubes de lectura

con un enfoque

crítico para

fomentar prácticas

de literacidad
A criação de clubes

de leitura com uma

abordagem crítica

para promover

práticas de

alfabetização
Camila Chaves Barrera* Orcid: https://orcid.org/0000-0003-1339-2448

Claudia Marcela Chapetón*** Orcid: https://orcid.org/0000-0002-7516-1082

* Magíster en Enseñanza de Lenguas Extranjeras. Directora Departamento de Inglés, Fundación Universitaria Panamericana.

Correo electrónico: acchavesb@unipanamericana.edu.co.

** Doctora en Lingüística Aplicada a la Enseñanza del Inglés. Docente e Investigadora del Departamento de Lenguas y del Doctorado Interinstitucional en Educación-DIE, Universidad Pedagógica Nacional.

Correo electrónico: cchapeton@pedagogica.edu.co. (c) (1) $(9$

Para citar este artículo

Chaves, C. y Chapetón, C. M. (2019). Creating a Book Club with a Critical Approach to Foster Literacy Practices. Folios, 50, 111-125. doi: 10.17227/Folios.50-10224 


\section{Abstract}

This paper reports the pedagogical experience of creating a book club to foster the reading of short stories from a critical literacy perspective at a high school in Bogotá, Colombia. The Book Club arose as an after-school program where students, who were interested in the proposal, were free to join. First, the paper presents the fundamental concepts that guided the implementation. Then, it describes the central elements of the pedagogical experience: context, curricular platform, procedures, and activities. The final discussion centers on the role of a critical literacy approach that encouraged participants to go beyond concerns about the grammatical and linguistic aspects of the foreign language to focus on meaning-making. Also, to concentrate on responding and transacting with the texts while engaging in dialogic interactions that allowed them to share background knowledge, life experiences, social and individual issues of their realities and interests, and most importantly, enjoy the act of reading in a foreign language as it was seen as a social-situated practice.

\section{Key words}

critical literacy; Rosenblatt's transactional theory; literary genres; foreign language teaching; extracurricular activities

\section{Resumen}

Este artículo informa sobre la experiencia pedagógica de creación de un club de lectura para promover la lectura de cuentos cortos desde una perspectiva crítica de la literacidad en un colegio de secundaria en Bogotá, Colombia. El Club de lectura surgió como una actividad extracurricular en la cual, las estudiantes que estuvieran interesadas podían participar libremente. El documento presenta, en primer lugar, los conceptos fundamentales que guiaron la implementación. Luego, describe los elementos centrales de la experiencia pedagógica: contexto, plataforma curricular, procedimientos y actividades. La discusión final se centra en el papel del enfoque de alfabetización crítica que alentó a los participantes a ir más allá de las preocupaciones relacionadas con aspectos lingüísticos o gramaticales de la lengua extranjera para enfocarse en construir significado. Además, para concentrarse en responder y negociar con los textos involucrándose en interacciones dialógicas que les permitieron compartir conocimiento previo, experiencias de vida, problemáticas sociales e individuales de sus realidades o intereses y, lo más importante, disfrutar del acto de leer en una lengua extranjera ya que este fue considerado como una práctica social situada.

Palabras clave

literacidad crítica; teoría transaccional de Rosenblatt; géneros literarios; enseñanza de lenguas extranjeras; actividades extracurriculares; club de lectura

\section{Resumo}

Este artigo relata a experiência pedagógica da criação de um Clube de Leitura para promover a leitura de contos de uma perspectiva crítica da alfabetização em uma escola secundária em Bogotá, Colômbia. 0 Clube de Leitura foi criado como uma atividade extracurricular na qual os alunos interessados poderiam participar livremente. A perspectiva crítica motivou os participantes a ir além de suas preocupações relacionadas a aspectos lingüísticos ou gramaticais da língua estrangeira para se concentrar na construção de significado, responder e negociar com os textos para engajar-se em interações dialógicas que lhes permitiu compartilhar conhecimento prévio, experiências de vida, problemas sociais e individuais de suas realidades ou interesses e, mais importante, desfrutar do ato de ler em uma língua estrangeira, uma vez que esta era considerada uma prática social localizada.

\section{Palavras-chave}

alfabetização crítica; teoria transacional de Rosenblatt; contos; ensino de línguas estrangeiras; clube de leitura 


\section{Introduction}

A relevant role has been given to reading and writing in many classrooms where English is taught as a foreign language $-\mathrm{EFL}-$. Most high school institutions in Colombia include their teaching and learning because these practices seem to be considered as abilities that allow learners to access knowledge and society. Traditional approaches to reading such as coding and decoding processes are commonly used by EFL teachers to encourage students' performance in the foreign language through an emphasis on grammar, decontextualized vocabulary, and spelling activities. Though this issue has been identified as problematic by some EFL teacher-researchers (e.g. Chapetón and Chala, 2013; Clavijo, 2016; Leal and Gómez, 2016; Viáfara, 2008; Zauscher, 2002) still, little research has been conducted to understand reading and writing as critical literacy practices that may enrich individual and social actions such as building human relationships, promoting awareness as members of a particular community, and questioning the immediate reality, thus focusing more on the social than on the linguistic when teaching the foreign language at schools.

Therefore, it seems to be essential to explore alternatives that can help EFL teachers to detach, at least to some extent, from the strong focus on the linguistic and the textual when reading and writing in the EFL classroom and promote literacy practices that may make the learning of the language a more meaningful, engaging, and pleasant activity. As argued by Chapetón (2005) "developing alternative reading programs can contribute a lot to the education of individuals as social readers" (p. 4) since these spaces may foster self and free expression, dialog, and discussion, and thus, the social construction of meaning.

From a critical perspective, the use of short stories in the classroom may motivate the love for reading. Also, it may encourage linguistic, social, personal, moral, and emotional experiences (Mubarak, 2013). Hence, this pedagogical proposal emerged as an opportunity to promote reading framed within a critical literacy approach that engaged a group of high school students in reading practices. These practices focused on the experience of reading the text and the world (Freire and Macedo, 1987), on students' responses to reading (Rosenblatt, 2002), and how those reading responses could be useful for participants to achieve individual and social purposes, that is, literacy understood as a situated social practice (Baynham, 1995).

In this article, we report the creation, development, and accomplishments of the Book Club created and implemented as a pedagogical opportunity to approach literacy from a critical perspective which may help students to reflect upon their realities, and, to recognize the importance of otherness in their lives. Teachers might find this experience useful to go beyond the traditional grammatical and linguistic approaches and foster the joy for reading in their English language teaching practice.

\section{Fundamental Concepts}

\section{Critical Pedagogy as the Foundation for Dialogical Education}

Education is about love, dialogue, and transformation (Freire, 1970, 2005, 2014, 2016). From there, we can rediscover ourselves and the otherness recognizing all the possibilities that exist in order to create a better world to live in. This implies understanding, humility, respect, and dialogue. Critical pedagogy involves commitment to others in a horizontal relationship where the purpose is to be free. The foundation of dialogue is love and love is dialogue itself. Dialogue cannot exist, however, in the absence of a profound love for the world (Freire, 1970, 2016). This idea portrays the main objective of pedagogy from a critical perspective considering a social approach to education that differs from the traditional one; it aims at giving opportunities to transform the world.

Usually, knowledge has been considered as something that needs to be consumed, transmitted, retained, and used to fit adequately in society. Freire $(1970,2014)$ defines it as the banking education in which students are receptacles that need to be filled; 
they store the knowledge accepting the world as it is presented. Therefore, learners and teachers perform a passive role characterized by lack of creativity, questioning, and reflection. Hence, students' learning experience discourages them to make their own meanings, to broaden their cultural knowledge, or to evaluate their own classroom experiences (Giroux, 2011). Unfortunately, many adolescents at high school experience learning from the traditional banking view of education, at least in one of their classes. In EFL classes, reflection and questioning are unusual and the performance on grammar and spelling tend to bear greater relevance. On the contrary, when seeing education from a critical perspective, knowledge is a social construction built by assumptions and particular interests that the individual has such as life experiences or future expectations. Also, it helps human beings to understand the processes behind knowledge production, appropriation, and transformation in specific contexts like home, school, and the classroom.

Critical pedagogy framed this pedagogical experience as its purpose was to create a particular community of EFL readers that were given possibilities to read the world around them by taking in meaningful topics related to their family, scholar, and social experiences to enrich learning, enjoy the act of reading, and promote humanizing actions in this particular high school setting. Thus, the Book Club became a place where knowledge was gained and shared through dialogue, questioning, and reflection about socially situated issues.

\section{Literacy as a Socially Situated Practice}

Considering literacy as a situated social practice implies defining literacy as the use of reading and writing to achieve social purposes in specific contexts (Baynham, 1995). It goes beyond bringing background knowledge and personal histories to the literacy event as it encourages students "to explore collectively the broader social context in which literacy is used" (Hamilton, 2010, p. 10). This approach thus moves from a focus on the individual towards a focus on the social because the learner can profit from reading and writing to achieve social changes such as awareness on environmental issues or questioning of quality in education, instead of considering literacy as a skill that a person needs to have in order to fit into a society. According to Gee (2013), the meaning of words, phrases, and sentences is always situated, that is, customized to our actual contexts. Then, literacy is a situated and social practice because it is "a process of interaction of different dimensions" (Chapetón, 2007, p. 35) such as the reader's background knowledge in interaction with linguistic knowledge, socially derived knowledge, and interpretative work, where meaning construction is at the core.

This process of meaning construction was developed in different moments of the pedagogical experience. First, students tried to construct meaning focusing on the linguistic and the textual; then, they attempted to assembling meaning with others, this means, with the text and peers; and finally, they went beyond words by building meaning through their personal experiences, dialogical transactions, and reflection. Therefore, students constructed the meaning through these moments that were followed interchangeably according to each one's reading experience and the specific reading event. That was the reason to use students' L1 (Spanish) as a facilitator for involvement, questioning, and participation. In other words, the L1 was recognized as part of students' background knowledge schemata, and it was used to belong and create sharing opportunities which permeated all the situated literacy experience.

\section{Reader's Response and Rosenblatt's Transactional Theory}

Reading implies the presence of a reader who experiences different universes with his/her own eyes. Through that reading experience, the reader responds to the world introduced by a specific text. As Rosenblatt (2002) believes, reading is a personal experience that takes place in a particular context and at particular time where selective and constructive processes unfold. 
Reading involves the consciousness and emotions of a particular reader (Rosenblatt, 2002). Therefore, each reading act or event presents a unique opportunity where meaning happens during the transaction between the reader and the text. Rosenblatt (2013) names this meaning that is felt to correspond to the text as evocation to cover both the efferent (focused on factual information) and aesthetic transactions (focused on lived-through meaning).

Building up on Dewey (1967) who differentiates interaction from transaction, Rosenblatt (1985) suggests that instead of the word interaction, that implies separated entities acting on the literary work, the word transaction should be used to designate the relationships among mutually conditioned elements. As Rosenblatt (2002) explains, the term "transactional" considers each reading as a particular event that involves a particular reader and a particular text that affect mutually and occasionally in particular circumstances. Then, the reader and the text are both important and entwined in a process as a whole rather than acting as separated entities. Consequently, a text is brought to life when a reader enters into a transaction with it; a reader reads and makes meaning of a text when both, the reader and the text are mutually essential to the transaction. The meaning created during this transaction is, then, influenced by physical, personal, social, and cultural factors that condition the situation where the reading event takes place.

Reading transactions in the Book Club were essential as it also took a critical perspective on reader's response. According to Marshall (2000) the critical tradition, or usually called literary theory or reader response theory, states that personal and contextual situation of the reader affects the reading. Critical tradition theorists can be divided into three different groups: theorists who find the source of literary meaning in the physiological identity and autobiographical history of readers themselves; those who place the source of literary meaning in a set of conventions that are shared by the reader and the author; and those who focus more on individual responses, that are shaped by social and cultural assumptions, locating a powerful source of readers' responses in the sociocultural context in which they are reading. This latter situated perspective goes hand in hand with the purpose of this pedagogical experience which considers reading and writing as situated social practices where meaning construction is central.

\section{The Book Club as an Opportunity}

\section{for Meaningful Reading}

According to McMahon and Raphael (1997) a book club is a student-led discussion where participants read literary selections, write responses to text, and engage in both small-group and whole-class discussions. A book club primary objective is to create a context where students can engage in meaningful conversations about the texts they read. Therefore, a book club is an opportunity to see how students are involved in a literacy practice situated at a particular time, place, and social context. Here, the teacher needs to begin considering students' initial reactions to the text to further these responses and to enable readers to know the opinions of others while returning to the text for further reflection (McMahon and Raphael, 1997).

Exist other ways to have access to literary discussions such as reading groups and literature circles. However, they present certain features that make them different from book clubs. The difference between these and reading groups, as stated by O'Donnell (2006), is that the teacher controls discourse in reading groups helping students with pronunciation and checking comprehension of literal details found in the passage because reading aloud is commonly used. In contrast, book clubs allow students to read aloud as a personal choice in service of interpretation and meaning construction. In regard to literature circles, O’Donnell (2006) mentions some differences such as role sheets, membership, and discussion topics. About role sheets, literature circles use them to designate each reader a role (connector, questioner, literary luminary, illustrator, etc.) centering the reader's response to this tool. Concerning membership, once members 
finish the job assigned to them, they decide where to go next depending on the text they want to read. As for discussion topics, in literature circles, discussion topics come only from students.

Since book clubs offer a situated space to discuss literary texts, they consider literacy going hand in hand with the self-social construction of individuals, and this is directly related to the purpose of literacy as a situated social practice. The Book Club implemented in this pedagogical experience draws on Reader's Response Theory (Rosenblatt, 1985, 1994, 2002) enabling students to generate and share their personal responses to different texts. The Book Club encounters prompted readers to build interpretation together through experience, dialogue, and reflection.

\section{Description of the Experience}

This section is the core of this paper as it describes and discusses the details of the pedagogical experience. In the following subsections, we provide an account of the context and participants, the curricular platform of the Book Club created, and the key issues related to its implementation which includes the selected material, the moments in which it developed, and the activities done during the different sessions.

As said before, the context in which this intervention was carried out was a high school establishment. It was a private Catholic institution located in Bogotá, Colombia. The group that took part in this study comprised seven students who volunteered to be involved in the Book Club offered after the regular class schedule at the school. They were female eleventh graders who were around sixteen and seventeen years old. As the Book Club sessions took place after the regular school schedule and each session lasted 2 hours, access to participants was based on their interest to take part in the experience.

\section{The Curricular Platform of the Book Club}

As a starting point in the creation of the book club, a curricular platform was built up to frame this pedagogical experience. It consists of the visions of curriculum from an emancipatory perspective, language as self-expression, learning as a social and cultural situated practice, and the classroom viewed as a place for socialization that served as the pedagogical backup of the implementation. This important component of the intervention is developed and presented as follows.

\section{Vision of Curriculum}

Grundy (1987) considers curriculum as a cultural and social construction and a way of organizing a set of human practices, which in this case is held by the Book Club from the perspective of emancipatory interest that holds an existential, empowering, and ideological-critical view of curriculum. Habermas and Lenhardt (1973) state that emancipatory interests aim at emancipation through reflection. Thereby, curriculum objectives deal with problem solving approaches, critical issues, and social studies. Also, an emancipatory interest promotes participation, engagement, student voice, and realization of individual and collective existential freedoms. These characteristics framed the design and development of each Book Club session where participants were encouraged to express and share their voices through reflection and dialogue.

\section{Vision of Language}

This pedagogical experience embraces a vision that considers language not only as a tool to achieve communicative goals, but also as a means of selfexpression where the language we use helps us to understand ourselves, people, and the way others perceive us (Tudor, 2001). In the Book Club, participants are encouraged to use language to respond to short stories reading by expressing, reflecting, discussing, sharing, writing, and making individual and collective connections with the world they live in and what they read.

Considering language as self-expression provides a humanistic perspective that focuses on personal fulfillment. In this sense, the Book Club goes beyond a system that contains grammar, vocabulary, and phonological parameters (Tudor, 2001). Instead, language is a situated social practice that is problematized and 
engaged in a critical activity (Baynham, 1995), in other words, the use of the language during the Book Club experience is seen as a means to express feelings, emotions, concerns, needs, and interests while replying to short stories through sharing and dialogical transactions. Thus, language is both rooted in social contexts and in turn, it builds up those contexts when used by the participants.

\section{Vision of Learning}

This pedagogical intervention views learning as a socio-culturally situated practice (Vygotsky, 1978). Vygotsky asserts that learning occurs even before starting a scholar formal learning process. Students are exposed to real-life situations that make them use their informal knowledge to solve problems they may face. When they are involved in a formal learning environment, they learn in a more systematic and scientific way. That is the reason why social interaction is a key factor in learning, as it gives learners the chance to learn from their daily life encounters influencing their mental development. This view of learning connects with the previously explained vision of language: learners define their own learning goals according to what they wish to express having a unique and personal learning agenda.

\section{Vision of Classroom}

The Book Club changes the traditional view of classroom contexts in three ways: first, students consider themselves and the others as active contributors to the learning environment. Second, there is a context rich in language that allows learners to express their thoughts, feelings, and experiences. Third, there is a context that provides opportunities for the teacher to promote students' involvement (McMahon and Raphael, 1997). In book clubs, students are using literacy by talking with each other, sharing ideas and feelings, and building upon their shared knowledge in developing their community. Thus, creating a context in which students are active participants in a specific community supports meaning construction.

According to Tudor (2001) when the classroom is a place where agendas of social nature are carried out in addition to, or by means of, language learning, that represents "classroom as socialization" (p. 123). The social dimension of the classroom from this vision could be perceived as imposed socialization (influenced by the system of values and beliefs where the classroom is situated) or emergent socialization (under the influence of local situations that are significant for the specific population in the classroom). During the Book Club sessions, the angle of emergent socialization framed each encounter first, because of the critical literacy stance taken and second, because the short stories narrated events significant to the participants as they related to students' realities such as family relationships, rejection at school, and classroom life being highly connected to their own lives.

\section{Implementation of the Book Club}

The Book Club was a place where participants had the opportunity to get involved in an EFL critical literacy practice, using the language to reflect, share, and engage in dialogical transactions with their peers to discuss their thoughts and ideas and express their feelings. Participants read a variety of short stories that connected to their realities as adolescents such as family relations, school life experiences, rejection, and decision making. To achieve these purposes, the criteria for material selection as well as the moments and activities developed during the Book Club sessions had a careful design.

\section{Material Selection}

The literary works chosen for the development of the Book Club were socially situated, that is, they were in line with students' interests such as dealing with situations at home and school, a major characteristic to have in mind in material selection (Lazar, 1993). Similarly, Collie and Slater (1991) state that one primary factor in selecting the literary text is the kind of personal involvement, interests, and reactions the text may arise in the reader. All the short stories used during the Book Club were close to students' current realities. When a text involves insights into family, school, or daily life-related issues which are close to the heart of peoples' concerns, the reader feels delighted of finding thoughts or situations as a part of her/his own life, the same delight of 
encountering those same thoughts or situations seen from a totally new, unexpected perspective (Collie and Slater, 1991).

According to Rosenblatt (2002), the more varied the literary selection is, the more educational, liberating strength it will have. The students read not only literature in the English language, but also, they perceived lifestyles, moral and social codes different or similar to the ones they experienced as part of their daily life. This happened for instance when reading stories such as “Three Wise Guys" by Sandra Cisneros and "Thank You, M'am" by Langston Hughes that include the delivery of gifts on January the Sixth instead of Christmas and reactions towards being a victim of a robbery, respectively. Then, the variety of short stories provided students with the opportunity to have a wide range of situations experienced by characters broadening their meaning construction when responding. The selected short stories portrayed this, as they are varied in cases, characters, and places that are related to school and family — classes, students, teachers, and parents- providing the Book Club with opportunities to have more varied discussions and reflections connected to the stories' themes and the students' lives. Table 1 presents the short stories selected for the development of this pedagogical experience. Each one of the sessions had different moments that were carried out considering some elements for their development. These moments are discussed in the subsequent section.

Table 1. Short stories used in the Book Club sessions.

\begin{tabular}{|c|c|c|}
\hline Short Story & Themes discussed & Summary \\
\hline $\begin{array}{l}\text { Three Wise Guys } \\
\text { by Sandra Cisneros }\end{array}$ & $\begin{array}{l}\text {-The hidden value of material things. } \\
\text {-Christmas and Sixth of January: } \\
\text { family traditions and expectations. }\end{array}$ & $\begin{array}{l}\text { This short story narrates how a family waits until } \\
\text { January the } 6^{\text {th }} \text { (Día de Reyes) to open a Christmas } \\
\text { gift and what happens to them when they, after } \\
\text { several guesses, discover what was inside. }\end{array}$ \\
\hline $\begin{array}{l}\text { I Confess... } \\
\text { by Wei WenJuan }\end{array}$ & $\begin{array}{l}\text {-Teachers' authority } \\
\text {-Students' reactions when facing } \\
\text { difficulties with teachers at school. }\end{array}$ & $\begin{array}{l}\text { This short story is about a recently graduated teacher } \\
\text { who works at his former school and a surprise he has } \\
\text { when he accuses a student in front of the class. }\end{array}$ \\
\hline $\begin{array}{l}\text { Thank You, M'am } \\
\text { by Langston Hughes }\end{array}$ & $\begin{array}{l}\text {-Reactions towards dealing with } \\
\text { a person you do not know. } \\
\text {-Reactions when experiencing a robbery. }\end{array}$ & $\begin{array}{l}\text { This short story describes how a woman kindly } \\
\text { helps a man who tried to steal her pocketbook and } \\
\text { how surprised he is because of her attitude. }\end{array}$ \\
\hline $\begin{array}{l}\text { The Dead Men's Path } \\
\text { by Chinua Achebe }\end{array}$ & $\begin{array}{l}\text {-Professional life expectations } \\
\text {-The consequence of making } \\
\text { rush decisions. }\end{array}$ & $\begin{array}{l}\text { The short story narrates what happens to the } \\
\text { new headmaster of a school who decided } \\
\text { to implement more progressive methods of } \\
\text { teaching to get rid of villager's superstitions. }\end{array}$ \\
\hline $\begin{array}{l}\text { Charles } \\
\text { by Shirley Jackson }\end{array}$ & $\begin{array}{l}\text {-School life experiences } \\
\text {-Family involvement }\end{array}$ & $\begin{array}{l}\text { Laurie is a boy that misbehaves in the school, so he } \\
\text { invents a boy named Charles. Then, he tells his parents } \\
\text { that Charles is a terrible boy, but he talks about himself. }\end{array}$ \\
\hline $\begin{array}{l}\text { All the Years of her Life } \\
\text { by Morley Callaghan }\end{array}$ & $\begin{array}{l}\text {-Family relations } \\
\text {-Consequences of wrong decision making. }\end{array}$ & $\begin{array}{l}\text { This short story depicts a mother's disappointment } \\
\text { when she finds out that her son steals stuff from his } \\
\text { workplace and how her son is shocked by her reaction. }\end{array}$ \\
\hline $\begin{array}{l}\text { What Happened } \\
\text { During the Ice-storm } \\
\text { by Jim Heynen }\end{array}$ & $\begin{array}{l}\text {-Group decisions } \\
\text {-How to act when being part of } \\
\text { a group and taking actions. }\end{array}$ & $\begin{array}{l}\text { A group of boys is playing in the ice when they see } \\
\text { some pheasants in danger, so one of the boys } \\
\text { decides to help them while the others follow him. }\end{array}$ \\
\hline $\begin{array}{l}\text { La puerta } \\
\text { by José Antonio Burciaga }\end{array}$ & $\begin{array}{l}\text {-Life expectations vs. Money } \\
\text {-Facing economic difficulties } \\
\text {-Family life }\end{array}$ & $\begin{array}{l}\text { This is the story of a poor couple who decide to } \\
\text { live in another country and the experiences they } \\
\text { go through because of buying a lottery ticket. }\end{array}$ \\
\hline $\begin{array}{l}\text { The Circuit } \\
\text { by Francisco Jiménez }\end{array}$ & $\begin{array}{l}\text {-Family life external conflicts } \\
\text {-Abilities or attitudes to face } \\
\text { unchangeable situations. } \\
\text {-Role of teachers in students' lives. }\end{array}$ & $\begin{array}{l}\text { This short story is about the life changes that a } \\
\text { migrant boy named Francisco experiences when he } \\
\text { and his family decide to live in the United States. }\end{array}$ \\
\hline
\end{tabular}




\begin{tabular}{|c|c|c|}
\hline Short Story & Themes discussed & Summary \\
\hline $\begin{array}{l}\text { The Princess and } \\
\text { the Tin Box } \\
\text { by James Thurber }\end{array}$ & $\begin{array}{l}\text {-The meaning of love } \\
\text {-Material things } \\
\text {-Consequences of making decisions }\end{array}$ & $\begin{array}{l}\text { There is a princess who needs to select a husband } \\
\text { among three different princes. She makes her decision } \\
\text { based only on the gifts each one of them offers her. }\end{array}$ \\
\hline $\begin{array}{l}\text { A Game of Catch } \\
\text { by Richard Wilbur }\end{array}$ & $\begin{array}{l}\text {-Actions to achieve collective goals } \\
\text {-Other's opinions } \\
\text {-Rejection }\end{array}$ & $\begin{array}{l}\text { This short story narrates how two boys } \\
\text { keep a boy from playing a game and what } \\
\text { the boy decided to do to annoy them. }\end{array}$ \\
\hline $\begin{array}{l}\text { Luck } \\
\text { by Mark Twain }\end{array}$ & $\begin{array}{l}\text {-Actions to achieve individual goals } \\
\text {-False showiness }\end{array}$ & $\begin{array}{l}\text { A man becomes a successful, recognized, and awarded } \\
\text { person by acting stupidly. He is in the right place } \\
\text { and the right time to have credit for doing nothing. }\end{array}$ \\
\hline $\begin{array}{l}\text { Shame } \\
\text { by Dick Gregory }\end{array}$ & $\begin{array}{l}\text {-Rejection at school } \\
\text {-Power relations in the classroom. } \\
\text {-Relationships with family at home. }\end{array}$ & $\begin{array}{l}\text { This is a short story that describes a boy } \\
\text { and his hard life and how a teacher in his } \\
\text { school rejects him in front of the class. }\end{array}$ \\
\hline
\end{tabular}

Source: Own elaboration.

\section{Book Club moments}

The Book Club sessions comprised six different moments: the world in the head, reading the text, reading the world, responding to worlds, reading otherness, and what if. Each one had a specific purpose and activity to encourage readers to reply to the short stories reading during the Book Club experience. The moments were connected among them being the World in the Head moment the trigger of the reflection and response.

Moment 1: The World in the Head. The purpose of this stage was to ignite participants' interest in the short story before reading it. Here, the goal was to foster students' curiosity in the reading trying to infer what the reading was about by answering questions that the teacher asked or other questions that the students posed from the title or from watching a short-related video clip. In this way, students activated their background knowledge schemata and recalled previous experiences about a particular situation (e.g., rejection in the classroom) that the text developed. They linked this to relevant previous experiences they had lived or to other people's experiences they knew about. Also, they were able to compare their knowledge about a specific situation (e.g., misunderstandings with relatives) with the previous knowledge of their partners, establishing links that made them find similarities and differences in their thoughts. These actions (the connections participants made between the text and previ- ous learning, relationships, and experiences) relate to the key tenets held in critical pedagogy and socially situated literacy of exploring and considering students' background knowledge and experiences in the classroom. Also, this prompted students to engage in reading transactions and response (Rosenblatt, 2002) from the very first encounter with the text.

Moment 2: Reading the Text. This part of the Book Club involved the actual reading of the short stories. To have participants engaged in the text, they received the explanation that it was possible to read it regardless they found some grammar or words difficult to be understood, which reflects the vision of language as a tool for personal fulfillment and self-expression this study embraced. The act of reading during the Book Club was performed in different ways: aloud, silently, or guided (McMahon and Raphael, 1997). Students decided the form or the teacher suggested it at the time of reading each particular short story.

Moment 3: Reading the World. During this stage, students discussed the initial ideas they had about the reading and which were shared during The World in the Head moment to see what connections or links could be made identifying issues that were similar or different to the meaning they made after reading. They shared their opinions about the meaning they made during this stage in the way they felt more comfortable with: by writing, drawing, or discussing. Participants were encouraged by the teacher 
to comment or to participate actively during the development of this moment by linking their readings of the word (short story) and the world (Freire and Macedo, 1987).

Moment 4: Responding to Worlds. During each one of the particular reading events and after them, the students were motivated to respond to the literary work by writing or drawing to express what they had lived-through the text. An oral and dialogical type of response was encouraged first. Here the teacher animated students to explore and express their feelings, emotions, and ideas as part of their transaction with the literary work. Subsequently, students were invited to respond to the reading in a written or visual way. This invitation asked them to take into consideration others' responses to enrich theirs.

Moment 5: Reading Otherness. In this point of the Book Club, there was a moment after the responding stage where students shared their reactions with other students, if they wanted to, by reading their writings or showing their drawings and then talking about the issues that called their attention the most. Also, students felt free to share orally what they had written as a response. During the development of this moment, the teacher promoted discussion as well as sharing and reflection.

Moment 6: What if...? At this stage, students thought about a question using the "What if...?" prompt to think about a variety of possibilities different from the ones that the short story presented. This prompt encouraged students to solve, deal, understand, and/or act on situations, characters, or events that emerged from the connections students made between the readings of the short story and the readings of their own life experiences and current reality. This activity fostered students' reflection upon the issues they have experienced in their daily life as they saw themselves living the same situations. Then, students were encouraged to write an answer for the question they had created as well as to share it with the group so that other students could answer different items from the one each one had created.
Pedagogical Activities: Promoting Response, Reflection, and Sharing.

Throughout each one of the moments developed in the reading encounters, readers' responses were promoted using thought-provoking questions and follow-up questions that emerged from the content of the text or previously shared responses, and "what if..." questions in Moment 6, precisely. Then, readers' responses could portray life experiences, textual references to the short story, connections between the text and background knowledge and those considering others' responses.

Each one of the reading moments in the Book Club aimed at fostering reflection upon students' realities through background knowledge activation, connections between the text and life experiences, and discussions upon shared reading responses. Reflections could elicit problem-solving, agency, and questioning on participants' issues about their families, school, and social interactions that emerged when listening and talking to others throughout the reading experience.

In each one of the Book Club moments, readers had the opportunity to share with the other participants by voicing or writing their thoughts, experiences, beliefs, and ideas through their predictions, opinions, questions, and responses to the short story reading, their partners' responses, or their own reflections that emerged throughout the development of the reading encounter.

Thus, since the purpose of this pedagogical experience was to create a space where students shared their reading responses by problematizing reality through dialogue (Freire and Macedo, 1987), all the activities were developed taking into account the students' interests as the core of the Book Club thus promoting response, reflection, and sharing. Then, planning of the actions articulated with the reading moments explained above and had in mind specific instructional objectives framed within a critical literacy approach. Table 2 presents a sample of the pedagogical activities developed around three of the selected short stories. It includes the instructional 
objectives, the main themes of each short story, and a description of the pedagogical activities developed in each one of the reading moments.

Table 2. Sample of the Pedagogical Activities developed in the Book Club sessions.

\begin{tabular}{|c|c|c|}
\hline \multicolumn{3}{|c|}{ IMPLEMENTING THE BOOK CLUB } \\
\hline \multicolumn{3}{|l|}{ Instructional Objectives } \\
\hline \multicolumn{3}{|c|}{$\begin{array}{l}\text { - To foster a book club that makes students feel comfortable and free to share their readings of the word and the world } \\
\text { - To identify students' ways to explore, enjoy and respond to the short stories reading. } \\
\text { - To encourage students' active participation during the reading encounters by } \\
\text { providing opportunities for reflection, dialogue and sharing. } \\
\text { - To foster different discussions that could take place during the reading encounters by exploring } \\
\text { life experiences, previous background knowledge, feelings and thoughts. }\end{array}$} \\
\hline SHORT STORY & MOMENTS & PEDAGOGICAL ACTIVITIES \\
\hline \multirow{6}{*}{$\begin{array}{l}\text { Three Wise Guys } \\
\text { by Sandra Cisneros } \\
\text { Themes: } \\
\text {-The hidden value of } \\
\text { material things. } \\
\text {-Christmas and Sixth of } \\
\text { January: family traditions } \\
\text { and expectations. }\end{array}$} & The World in the Head & $\begin{array}{l}\text { Students were invited to share their opinions about the } \\
\text { title of the short story animating them to express their } \\
\text { feelings or ideas about that possible world. }\end{array}$ \\
\hline & Reading the Text & $\begin{array}{l}\text { The teacher motivated students by reading the short } \\
\text { story aloud while they followed the reading. }\end{array}$ \\
\hline & Reading the World & $\begin{array}{l}\text { The whole group was invited to give opinions about } \\
\text { their first ideas and feelings and to see how those were } \\
\text { similar or different to the short story reading. }\end{array}$ \\
\hline & Responding to Worlds & $\begin{array}{l}\text { Students were encouraged to discuss their responses } \\
\text { to the reading of the short story. After a while, they } \\
\text { were asked to write or draw their responses. }\end{array}$ \\
\hline & Reading Otherness & $\begin{array}{l}\text { Students were invited to share with their partners } \\
\text { their responses as they preferred. }\end{array}$ \\
\hline & What if...? & $\begin{array}{l}\text { Students were encouraged to write a question using } \\
\text { 'what if...' to include a hypothetical situation that } \\
\text { related to their reflections after the reading. }\end{array}$ \\
\hline \multirow{6}{*}{$\begin{array}{l}\text { The Circuit } \\
\text { by Francisco Jiménez } \\
\text { Themes: } \\
\text {-Family life external conflicts. } \\
\text {-Abilities or attitudes to face } \\
\text { unchangeable situations. }\end{array}$} & The World in the Head & $\begin{array}{l}\text { Students were invited to watch an animated short video clip } \\
\text { (5:49 minutes) called Partly Cloudy, which is a Pixar animation } \\
\text { created by Peter Sohn in } 2009 \text {. This clip presents a story } \\
\text { about life changes, life situations, and love meaning. }\end{array}$ \\
\hline & Reading the Text & The students were motivated to read the short story aloud. \\
\hline & Reading the World & $\begin{array}{l}\text { The sharing made during the The World in the Head } \\
\text { moment was discussed after the reading aloud. }\end{array}$ \\
\hline & Responding to Worlds & $\begin{array}{l}\text { Students were asked to discuss their responses to } \\
\text { the reading. After a while, they were invited to share } \\
\text { their comments by talking, writing, or drawing. }\end{array}$ \\
\hline & Reading Otherness & $\begin{array}{l}\text { The students were more than welcome to share } \\
\text { their responses with the club members. }\end{array}$ \\
\hline & What if...? & $\begin{array}{l}\text { The teacher encouraged students to write a question using } \\
\text { what if... to include their reflections after the reading. }\end{array}$ \\
\hline
\end{tabular}


Universidad Pedagógica $\mathrm{Nacional}$

Facultad de Humanidades

\begin{tabular}{|l|l|l|}
\hline \multicolumn{1}{|c|}{ SHORT STORY } & \multicolumn{1}{c|}{ MOMENTS } & \multicolumn{1}{c|}{ PEDAGOGICAL ACTIVITIES } \\
\hline $\begin{array}{l}\text { Shame } \\
\text { by Dick Gregory }\end{array}$ & The World in the Head & $\begin{array}{l}\text { Students watched a short video clip taken from the movie Another Brick } \\
\text { in the wall and explored the text by expressing how they felt about it. }\end{array}$ \\
\cline { 2 - 3 } $\begin{array}{l}\text { Themes: } \\
\text {-Discrimination at school. } \\
\text {-Power relations in } \\
\text { the classroom. }\end{array}$ & Reading the Text & Students decided to read the short story silently. \\
\cline { 2 - 3 } & Reading the World & $\begin{array}{l}\text { The teacher invited the whole group to give opinions } \\
\text { about the first moment ideas and how they were } \\
\text { similar or different to the text that was read. }\end{array}$ \\
\cline { 2 - 3 } & Responding to Worlds & $\begin{array}{l}\text { Students were motivated to share their responses with the whole } \\
\text { group. Next, they were invited to write their responses. }\end{array}$ \\
\cline { 2 - 3 } & Reading Otherness & $\begin{array}{l}\text { Students were asked to share with their partners their } \\
\text { responses after the Responding to Worlds moment. }\end{array}$ \\
\cline { 2 - 3 } & What if...? & $\begin{array}{l}\text { Students were motivated to write a question using what if... including } \\
\text { a possible answer to it to include their reflections after the reading. }\end{array}$ \\
\hline
\end{tabular}

Source: Own elaboration.

\section{Discussion of the Implementation of a Book Club with a Critical Approach}

The pedagogical experience implemented as an after-school program generated changes in the way that participants approached literacy. The different short stories, moments, and activities of the Book Club contributed significantly to build up a critical perspective where responding to, transacting with, and living-through the literary text gave meaning to the act of reading. Figure 1 shows a visual representation of the way the different elements of the Book Club articulated. First, three key constructs provide the theoretical background that frames the proposal. These include a critical perspective on pedagogy, an understanding of literacy as a situated social practice, and the transactional and reader's response theories proposed by Rosenblatt $(1994,2002,2013)$. Second, the views of curriculum, language, learning, and classroom provide the framework to build up a system of beliefs about the main components of the teaching practice. With these in mind, a careful process of material selection takes place and a series of moments to develop the reading club are put forward having meaning-making at the core of the reading practice.

Three fundamental changes were witnessed during the development of this pedagogical experience. First, there was a move from a strong tendency to focus on grammar and vocabulary when reading texts in English to experience the act of reading as a

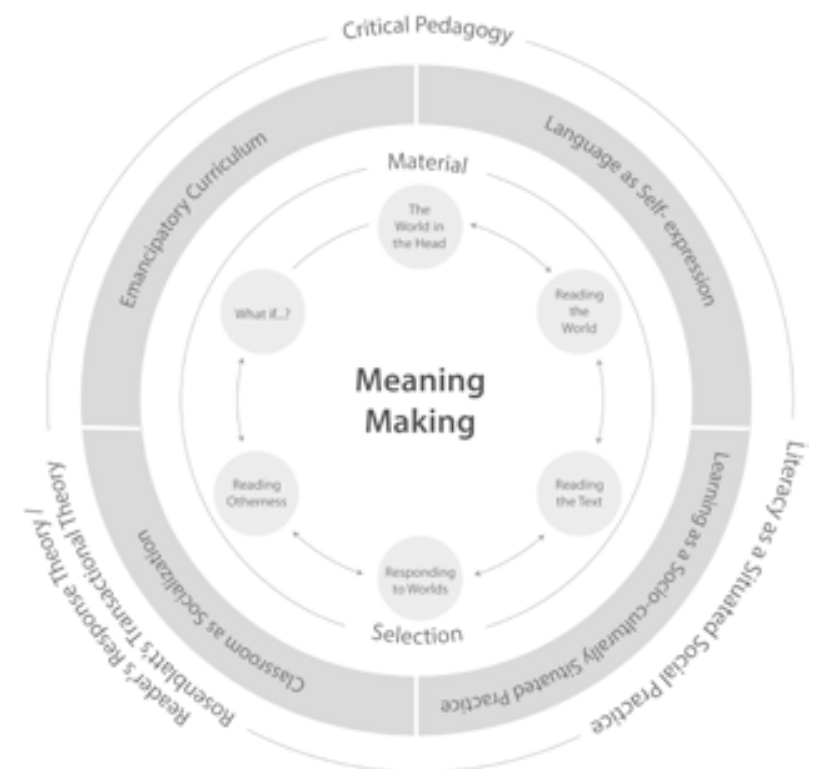

Figure 1. The components of the Book Club with a critical approach.

Source: Own elaboration.

meaningful practice where participants can interact with the text in a variety of ways that involved reflection, sharing, and dialogue. This move showed students that even though making use of their linguistic knowledge of the foreign language is important for interpretation; there are other elements from their background knowledge schemata that can be at play in meaning construction. Aspects such as socially derived knowledge, past experiences and even future expectations can shape the act of reading in ways 
students had not yet discovered in their traditional EFL classes.

Second, this pedagogical experience unveiled the move from disengaged readers to active readers willing to learn more about the world through literature and their own readings of the word and the world. Questioning the realities portrayed in the texts, comparing those realities to their personal and social lives, and reflecting upon those realities, engaged these students in meaningful readings. Those readings also encouraged them to think of possible actions that they could take as individuals or as members of a community (e.g., their school or their own families), to call for change in their local and national contexts. Then, they seemed to emancipate from their dominant realities by questioning some of their school regulations, teaching practices, and human nature.

Finally, these book club participants learned that they could approach the literary text from a critical literacy perspective. This perspective allowed them to make connections to their own lives, express their feelings as they emerged from the reading event, and have a voice that can be shared and enriched with others by reflecting upon themselves as members of a particular family, learning community, and society. Every time a text was read, there was a chance for students to express and to recognize their partners as human beings with similarities and differences such as feelings when being at home and school and expectations about future as professionals. This socially situated learning came from participants' interpretations of what they read, from their own experiences, and sharing of their understanding of the current reality that surrounded them as members of a particular learning community.

These three observed fundamental changes have meaning-making at their intersection. Students were confident enough to actively participate in EFL short story reading by drawing on their own experiences and background knowledge to respond, transact, and engage in reflection and dialogue, thus a sense of "ownership over meaning-making" (Norton,
2010, p. 4) was fostered to make the act of reading a meaningful, engaging, and pleasant literacy practice.

\section{Conclusion}

This paper has reported and described the experience of creating and implementing a book club with a critical literacy approach in an EFL context where meaning-making was at the core. The critical literacy approach along with Rosenblatt's response and transactional theories provided a framework to understand reading and writing as situated social practices. This framework also articulated a system of beliefs where the curriculum was viewed as emancipatory, language as self-expression, learning as a socio-culturally situated practice, and the classroom as a space for socialization. Thus, a process of material selection was undertaken to engage participants in reading short stories whose themes, characters, and plots were related to their own realities and life experiences. Also, the Book Club developed by dynamically going through different reading moments that invited participants to engage in literacy practices that explored the readers' backgrounds and their readings of their realities to then read and interact with the text by responding to it in different ways that involved their own experiences, feelings, reflections, concerns, and even expectations.

Promoting this kind of spaces where students have opportunities to construct meanings through dialogue and sharing should be considered by EFL teachers because these can enrich learning and teaching practices from self and social reflection going beyond coding and decoding practices. Moreover, the use of short stories in English is helpful as these connect different points of view that can be linked to students' lives making them feel like an important part of a particular community. Then, EFL literature may be perceived not only as a tool to learn the language but as a way to know, discuss, reflect, and act.

The role of the teacher during the Book Club was being a facilitator who listened to students' life 
experiences and realized how important it was to build confidence with students, in a manner that they felt with a teacher and a kind of friend at the same time, to promote sharing and involvement. Then, this may happen in a regular EFL class taking advantage of the spaces that reading has in the classroom. This perspective goes in line with Freire (1970, 2014, 2016) as he states that the role of the teacher is not of the one who teaches but the one who is being taught through dialogue with students mediated by the world to unveil and re-create reality.

A space for reading in EFL may provide students with the opportunity not only to learn the language but also to know and interpret the world that surrounds them. Regular EFL classes or after-school activities that involve critical literacy practices may offer a possibility for students to feel motivated not only towards language learning but also towards reading and enjoying literature. Clearly, as Norton (2010) claims "if learners have a sense of ownership of meaning-making, they can engage actively in a wide range of literacy practices; however, if there is little ownership over meaning-making, learning becomes meaningless and ritualized" (p. 10). In sum, this experience can be considered by EFL teachers as a pedagogical proposal that can take them, and their students, away from routine literacy practices and embark them in the pleasures of learning through meaningful reading, reflection, dialogue, and sharing.

\section{References}

Baynham, M. (1995). Literacy practice: investigating literacy in social contexts. New York and London: Longman.

Chapetón, M. (2005). Creating reading clubs that foster resiliency: Theoretical foundations. Folios, 21, 3-16.

Chapetón, C. M. (2007). Literacy as a resource to build resiliency. Bogotá: Fondo Editorial Universidad Pedagógica Nacional.

Chapetón, C. M., and Chala, P. A. (2013). Undertaking the act of writing as a situated social practice: Going beyond the linguistic and the textual. Colombian Applied Linguistics Journal, 15 (1), 25-42.
Clavijo, A. (2016). English teaching in the elementary school: Some critical issues. Colombian Applied Linguistics Journal, 18 (1), 4-10.

Collie, J., and Slater, S. (1991). Literature in the language classroom. Glasgow: Cambridge University Press

Dewey, J. (1967). Experiencia y Educación. Buenos Aires: Losada.

Freire, P. (1970). Pedagogy of the oppressed. New York: Continuum.

Freire, P. (2005). Teachers as cultural workers: letters to those who dare teach. United States: Westview Press.

Freire, P. (2014). Pedagogy of hope: Reliving pedagogy of the oppressed. London/New York: Bloomsbury.

Freire, P. (2016). Pedagogy of the heart. London/New York: Bloomsbury.

Freire, P., and Macedo, D. (1987). Literacy: Reading the word and the world. London: Bergin \& Garvey.

Gee, J. (2013). Reading as situated language: A sociocognitive perspective. In D. Alvermann, N. Unrau, and R. Ruddell. (Eds.), Theoretical models and processes of reading (6th ed., pp. 136-151). Newark, DE: International Reading Association.

Giroux, H. (2011). On critical pedagogy. London: Bloomsbury.

Grundy, S. (1987). Curriculum: Product or praxis? London: Falmer Press.

Habermas, J., \& Lenhardt, C. (1973). A postscript to knowledge and human interests. Philosophy of the Social Sciences, 3, 157-189.

Hamilton, M. (2010). The social context of literacy. In N. Hughes and I. Schwab. (Eds.), Teaching adult literacy: Principles and practice (pp. 7-27). Berkshire: Open University Press.

Lazar, G. (1993). Literature and language teaching. Cambridge: Cambridge University Press.

Leal, M., \& Gómez, L. F. (2016). Encouraging critical thinking development in an EFL classroom through urban legends. Folios, 43 (1), 137-152.

Marshall, J. (2000). Research on response to Literature. In M. Kamil et al (Eds.), Handbook of reading research (pp. 381-402), vol. 3. London: Lawrence Erlbaum.

McMahon, S. I., and Raphael, T. E., with V. J. Goatley and L. S. Pardo (1997). The Book Club connection: Literacy learning and classroom talk. New York: Teachers College Press. 
Mubarak, M. (2013). The use of short stories in EFL classroom: advantages and implications. Labyrinth, 4 (2), 21-26.

Norton, B. (2010). Identity, literacy, and English-language teaching. TESL Canada Journal, 28 (1), 1-13.

O'Donnell, C. (2006). The book club companion: Fostering strategic readers in the secondary classroom. Portsmouth: Heinemann.

Palacios, N., \& and Chapetón, C. (2014). Students' responses to the use of songs in the EFL classroom at a public school in Bogotá: A critical approach. Gist Education and Learning Research Journal, 9, 9-30.

Rosenblatt, L. (1985). Viewpoints: Transaction versus interaction: A terminological rescue operation. Research in the Teaching of English, 19 (1), 96-107.

Rosenblatt, L. (1994). The reader, the text, the poem: the transactional theory of the literary work. United States: Southern Illinois University Press.
Rosenblatt, L. (2002). Literatura como exploración. México: Fondo de Cultura Económica.

Rosenblatt, L. M. (2013). The transactional theory of reading and writing. In D. Alvermann, N. Unrau, and R. Ruddell. (Eds.), Theoretical models and processes of reading (6th ed., pp. 923-954). Newark, DE: International Reading Association.

Tudor, I. (2001). Visions of learning in the dynamics of the language classroom. Cambridge: Cambridge University Press.

Viáfara, J. J. (2008). From pre-school to university: student-teachers' characterize their EFL writing development. Colombian Applied Linguistics Journal, 10, 73-92.

Vygotsky, L. (1978). Mind in society: The development of higher psychological processes. Cambridge, MA: Harvard University Press.

Zauscher, D. (2002). Alternative strategies for EFL writing instruction. How, 9 (2), 49-52. 